Arkhais, Vol. 06 No. 2 Jufi - Desember 2015

\title{
KATEGORI FATIS BAHASA SUNDA SUKABUMI
}

\section{Rini Siti Parida Malik}

\begin{abstract}
Abstrak. Penelitian ini bertujuan untuk mendeskripsikan penggunaan kategori fatis bahasa Sunda Sukabumi. Penelitian ini dilaksanakan pada semester genap, yakni Februari-Juni 2015. Metode yang digunakan adalah metode deskriptif kualitatif. Instrumen yang digunakan adalah peneliti sendiri dibantu tabel analisis kerja. Objek dalam penelitian ini adalah percakapan bahasa Sunda Sukabumi yang berbentuk partikel dan kata (mencakup paduan, gabungan, dan perulangan), frasa, serta klausa atau kalimat fatis. Fokus penelitian ini adalah bentuk, distribusi, fungsi, dan makna kategori fatis bahasa Sunda Sukabumi. Data dalam penelitian ini adalah sepertiga total keseluruhan data, yakni 10 rekaman dari total 30 rekaman. Berdasarkan hasil penelitian, kategori fatis selalu hadir dalam percakapan informal bahasa Sunda Sukabumi. Kategori fatis bahasa Sunda Sukabumi ditemukan sebanyak 93 bentuk, dengan rincian partikel dan kata fatis sebanyak 24 fatis, paduan fatis sebanyak 14 fatis, gabungan fatis sebanyak 42 fatis, perulangan fatis sebanyak 2 fatis, frasa fatis sebanyak 6 fatis, dan klausa atau kalimat fatis sebanyak 5 fatis. Dengan demikian, bentuk kategori fatis yang penggunaannya paling dominan adalah gabungan fatis, yakni 42 fatis, sedangkan bentuk yang penggunaannya paling sedikit adalah perulangan fatis, yakni sebanyak 2 fatis. Sementara berdasarkan distribusinya, kategori fatis bahasa Sunda Sukabumi paling dominan berdistribusi di tengah kalimat, yakni sebanyak 166 penggunaan. Fungsi yang terkandung dalam kategori fatis bahasa Sunda Sukabumi sebanyak 9 fungsi, namun fungsi yang kemunculannya paling dominan adalah fungsi menegaskan pembicaraan, yakni sebanyak 132 kemunculan. Makna fatis yang muncul dalam kategori fatis bahasa Sunda Sukabumi sebanyak 14 makna. Makna yang kemunculannya paling dominan adalah fungsi menekankan kebenaran sebuah fakta, yakni sebanyak 136 kemunculan.
\end{abstract}

Kata Kunci: Kategori Fatis, Percakapan, Bahasa Sunda Sukabumi.

\section{PENDAHULUAN}

Bahasa Sunda merupakan salah satu bahasa daerah yang hidup di Indonesia. Jika ditinjau dari klasifikasi bahasa, bahasa Sunda adalah bahasa dari cabang Melayu-Polinesia yang termasuk ke dalam rumpun Austronesia bagian barat. Menurut perkiraan, bahasa Sunda digunakan oleh sekitar 19 juta penutur yang umumnya berdiam di daerah provinsi Jawa Barat, di sebagian daerah sebelah barat provinsi Jawa Tengah, DKI Jakarta, dan pusat-pusat transmigrasi. Bahasa Sunda terbagi menjadi beberapa dialek, diantaranya dialek Barat (Banten Selatan), dialek Utara (Bogor dan sekitarnya), dialek Selatan atau dialek Priangan (Bandung dan sekitarnya), dialek Tengah Timur (Majalengka dan sekitarnya), dialek Timur Laut (Kuningan dan sekitarnya), dan dialek Tenggara (Ciamis dan sekitarnya). Berdasarkan pembagian dialek tersebut, bahasa Sunda Sukabumi termasuk ke dalam lingkup dialek Priangan. Namun walaupun demikian, bahasa Sunda Sukabumi memiliki perbedaan dengan bahasa Sunda yang termasuk dalam dialek priangan lainnya. Perbedaan tersebut dapat berupa perbedaan fonologi, morfologi, maupun semantik.

Berdasarkan penggunaannya, bahasa Sunda mengenal tingkatan (undak-usuk) bahasa. Secara garis besar, tingkatan bahasa dalam bahasa Sunda dibagi atas tiga tingkatan, 
yaitu halus (lemes), sedang (loma), dan kasar. Bahasa Sunda halus biasanya digunakan kepada orang yang lebih tua, Sunda sedang digunakan untuk berkomunikasi dengan sebaya atau dengan orang yang usianya lebih muda, dan Sunda kasar digunakan untuk berkomunikasi dengan orang yang sudah sangat akrab. Namun dalam pemakaian seharihari, penggunaan tingkatan bahasa tersebut tidak selalu sesuai. Masyarakat Sukabumi lebih sering menggunakan bahasa Sunda yang tingkatannya sedang atau bahkan cenderung kasar dengan tujuan supaya tercipta suasana komunikasi yang lebih akrab serta tidak kaku. Oleh sebab itu, dalam percakapan yang dilakukan oleh masyarkat Sunda Sukabumi banyak termuat kategori fatis. Kridalaksana (2007:114) menyatakan bahwa kategori fatis merupakan kategori yang bertugas memulai, mempertahankan, mengukuhkan, atau mengakhiri pembicaraan dengan kawan bicara. Kategori ini sebagian besar terdapat dalam ragam lisan. Hal tersebut disebabkan karena ragam lisan pada umumnya merupakan ragam tidak baku. Kategori fatis sangat lazim dalam kalimat-kalimat tidak baku yang banyak mengandung unsur-unsur daerah atau dialek regional. Kategori fatis menurut Kridalaksana (2007:116) dapat berbentuk partikel dan kata serta frasa fatis, sedangkan Agustina (2007:54) dalam penelitiannya terhadap bahasa Minangkabau menambahkan klausa atau kalimat fatis sebagai bentuk kategori fatis.

Bentuk-bentuk fatis tersebut mengandung fungsi dan makna dalam pertuturan. Namun, penutur kadang kala tidak menyadari bahwa dalam dialog yang mereka lakukan termuat ungkapan fatis, baik fatis yang berbentuk partikel atau kata, frasa, maupun klausa atau kalimat. Hal tersebut diakibatkan karena memang sudah menjadi suatu kebiasaan, bahwa ketika berdialog harus seperti itu. Fungsi fatis pun dipahami sekadar untuk menjalin hubungan yang lebih akrab antara penutur dengan kawan tutur. Padahal, ungkapan fatis memiliki fungsi dan makna yang beraneka dalam pertuturan. Bahkan, penggunaan bentuk kategori fatis yang sama dapat menimbulkan fungsi serta makna yang berbeda.Berdasarkan latar belakang masalah di atas, maka rumusan masalah dalam penelitian ini adalah bagaimana kategori fatis bahasa Sunda Sukabumi. Rumusan masalah tersebut diharapkan dapat memberikan deskripsi mengenai penggunaan kategori fatis bahasa Sunda Sukabumi berdasarkan distribusi, bentuk, fungsi, dan maknanya dalam pertuturan.

\section{METODOLOGI PENELITIAN}

Metode yang digunakan dalam penelitian ini adalah metode deskriptif kualitatif. Penelitian ini menjelaskan penggunaan bentuk, distribusi, fungsi, dan makna kategori fatis dalam bahasa Sunda Sukabumi.Data dalam penelitian ini adalah ungkapan berbentuk partikel atau kata, frasa, dan klausa atau kalimat yang memiliki fungsi fatis. Data berada pada rekaman percakapan, yakni berupa satuan ujaran yang mengandung ungkapan fatis. Data dalam penelitian ini bersumber pada percakapan bahasa Sunda Sukabumi. Adapun kriteria responden yang digunakan dalam penelitian ini diantaranya adalah penutur asli bahasa Sunda Sukabumi, sehat jasmani rohani, tidak cacat pelafalan (artikulator jelas), dan berusia 7 sampai 65 tahun.Responden yang digunakan dalam satu rekaman minimal berjumlah dua orang. Hal tersebut disebabkan karena penelitian kategori fatis dalam ragam lisan ditemukan dalam dialog. Responden dalam penelitian ini berjumlah 30 pasang responden atau 30 rekaman percakapan. Rekaman percakapan yang digunakan sebagai sumber data dipilih secara acak (random), sehingga rekaman yang digunakan sebagai sumber data hanya sepertiga dari total rekaman keseluruhan, yakni 10 rekaman dari 30 rekaman percakapan.

Metode pengumpulan data dilakukan dengan beberapa langkah, yakni (1) observasi secara langsung terhadap masyarakat Sunda Sukabumi. Observasi dilakukan dengan mengamati dan mencatat hal-hal yang berkaitan dengan fokus penelitian; (2) merekam 
percakapan yang dilakukan oleh penutur asli Sunda Sukabumi dengan metode sadap rekam, yakni peneliti tidak ikut serta dalam percakapan yang dilakukan atau peneliti berperan sebagai perekam pasif. Hal ini dilakukan supaya pembicaraan yang direkam bersifat alami dan tidak dibuat-buat; (3) mentranskripsi hasil rekaman, yakni mengalihbentukkan dari ragam lisan menjadi ragam tulis; (4) mengidentifikasi data yang telah diperoleh berdasarkan bentuk, distribusi, fungsi, dan makna yang terdapat dalam partikel dan kata fatis (mencakup paduan, gabungan, dan perulangan fatis), frasa, serta klausa atau kalimat fatis. Metode analisis data yang digunakan dalam penelitian ini adalah (1) reduksi data dilakukan dengan membaca berulang-ulang percakapan bahasa Sunda Sukabumi yang telah ditranskripsi, kemudian dikelompokkan berdasarkan kriteria analisis yang sudah ditentukan sesuai dengan fokus penelitian. Reduksi data juga diperlukan untuk mengurangi atau menyeleksi data yang akan digunakan sebagai sampel; (2) Penyajian data dilakukan dengan menyajikan data yang telah dikelompokkan berdasarkan bentuk, distribusi, fungsi,dan makna kategori fatis. Penyajian data dilakukan untuk mendeskripsikan sebagian atau keseluruhan data hasil penelitian. Data disajikan dalam bentuk tabel analisis kerja yang telah disesuaikan dengan kriteria analisis; (3) Penarikan kesimpulan dilakukan selama penelitian berlangsung. Hal tersebut dilakukan untuk mengetahui kesatuan dan kepaduan data. Data yang telah disajikan kemudian ditarik kesimpulan berdasarkan kriteria yang akan dianalisis, yakni bentuk, distribusi, fungsi, dan makna kategori fatis; (4) Verifikasi dilakukan dengan tujuan untuk menguji keabsahan data primer.

\section{HASIL DAN PEMBAHASAN}

Pembahasan hasil penelitian mengenai distribusi, fungsi dan makna fatis bahasa Sunda Sukabumi akan dilakukan berdasarkan bentuk-bentuk kategori fatis.Bentuk partikel dan kata yang muncul dalam percakapan bahasa Sunda Sukabumi sebanyak 24 fatis (25.8\%). Bentuk ini dapat berdistibusi di awal, tengah, dan akhir kalimat. Partikel dan kata fatis yang hanya berdistribusi di awal kalimat adalah nyéta, tuh, heueuh, éh, yéh, duh, ih, halow, dan hayu, sedangkan yang berdistribusi di tengah yaitu waéh dan yeuh.Partikel dan kata fatis yang berdistribusi di awal dan tengah adalah $a h$, $d a$, dan sing. Partikel fatis yang berdistribusi di tengah dan akhir terdiri dari mah, téh, atuh, lah, lin, dan téa. Sementara itu, partikel dan kata fatis yang menempati semua posisi, yakni di awal, tengah, dan akhir adalah ning/geuning, tah, pan/apan, dan nya/nya(h). Partikel dan kata fatis yang berdistribusi di awal berjumlah 55 fatis, di tengah 94 fatis, dan di akhir berjumlah 59 fatis.Berdasarkan fungsinya dalam tuturan, partikel dan kata fatis yang berfungsi untuk mematahkan pembicaraan adalah ah, mah, dan ih. Partikel fatis yang berfungsi menekankan ajakan adalah hayu. Partikel fatis yang berfungsi menegaskan pembicaraan adalah ah, mah, téh, ning/geuning, pan/apan, nya/nyah, da, tah, atuh, nyéta, tuh, yéh, sing, téa, duh, duh, dan yeuh.

Partikel fatis yang berfungsi meyakinkan pembicaraan adalah mah, téh, ning/geuning, pan/apan, da, tah, lah,heueuh, eh, dan waéh. Partikel fatis yang berfungsi untuk meminta persetujuan atau pendapat kawan bicara adalah nya/nya(h). Partikel fatis yang berfungsi mengukuhkan pembicaraan adalah mah, téh, ning/geuning, pan/apan, nya/nya(h), da, heueuh, dan lah. Partikel fatis yang berfungsi untuk mengawali pembicaraan adalah nya/nya(h) dan halow, sedangkan partikel yang mengakhiri pembicaraan adalah nya/nya(h) Partikel dan kata fatis berfungsi untuk mematahkan pembicaraan, yakni sebanyak 5 fatis, fungsi menekankan ajakan sebanyak 1 fatis, fungsi menegaskan pembicaraan sebanyak 76 fatis, fungsi meyakinkan pembicaraan sebanyak 72 fatis, fungsi meminta persetujuan atau pendapat kawan bicara sebanyak 6 fatis, fungsi 
mengukuhkan pembicaraan sebanyak 32 fatis, fungsi membentuk kalimat interogatif sebanyak 25 fatis, fungsi mengawali pembicaraan sebanyak 2 fatis, dan fungsi untuk mengakhiri pembicaraan sebanyak 1 fatis. Fungsi partikel dan kata fatis yang paling sering muncul adalah fungsi menegaskan pembicaraan.

Sementara berdasarkan maknanya, partikel dan kata fatis bermakna menekankan bantahan, yakni termuat dalam partikel ah, mah, dan nyéta, menekankan keingintahuan termuat dalam mah, téh, nya/nya(h), atuh,tea dan lin, menekankan keheranan termuat dalam mah, ning/geuning, da, dan pan/apan, menekankan kesungguhan termuat dalam ah, mah, téh, nya/nya(h), da, tah, atuh, lah, heueuh, éh, yéh, duh, ih, dan hayu. Makna menghaluskan paksaan termuat dalam partikel ah, mah, téh, da, atuh, nyéa, tuh, téa. Makna menekankan kekesalan termuat dalam tah, lah, hеuеuh, dan pan/apan, menekankan kebenaran sebuah fakta termuat dalam ah, téh, mah, ning/geuning, nya/nya(h), da, tah, atuh, nyéta, lah, heueuh, sng, waéh, pan/apan, dan yeuh, serta makna menekankan basabasi termuat dalam kata fatis halow. Berdasarkan maknanya, partikel dan kata fatis bermakna menekankan bantahan muncul sebanyak 7 fatis, menekankan keingintahuan sebanyak 26 fatis, menekankan keheranan sebanyak 8 fatis, menekankan kesungguhan sebanyak 38 fatis, menghaluskan paksaan sebanyak 9 fatis, menekankan kekesalan sebanyak 8 fatis, menekankan kesetujuan sebanyak 12 fatis, menekankan fakta yang sebenarnya sebanyak 92 fatis, dan makna menekankan basa-basi sebanyak 1 fatis.

Paduan fatis dalam percakapan bahasa Sunda Sukabumi ditemukan sebanyak 14 fatis (15\%). Paduan fatis berdistribusi di awal, tengah, dan akhir kalimat. Paduan fatis yang berdistribusi di awal adalah héh atuh, nuhun ah, hayu ah, woya atuh, wah da, dan hayo(h) atuh, heueuh pan, dan heueuh da. Paduan fatis yang berdistribusi di tengah adalah mah $d a$, mah pan, atuh nya, dan mah ning/mah geuning, sedangkan yang berdistribusi di akhir adalah téa lin. Sementara itu, paduan fatis atuh da berdistribusi di awal dan tengah. Bentuk paduan fatis yang berdistribusi di awal sebanyak 12 fatis, di tengah 7 fatis, dan di akhir sebanyak 1 fatis.Berdasarkan fungsinya, paduan fatis yang berfungsi untuk mematahkan pembicaraan adalah wah da, paduan fatis untuk menekankan ajakan adalah hayu ah, woya atuh, dan hayo(h) atuh. Paduan fatis yang berfungsi untuk menegaskan pembicaraan adalah héh atuh, nuhun ah, hayu ah, atuh nya, woya atuh, mah ning/mah geuning, heueuh $d a$, heueuh pan, dan hayo(h) atuh. Fungsi paduan fatis untuk meyakinkan pembicaraan adalah mah da, mah pan, dan mah ning/mah geuning, fungsi untuk meminta persetujuan atau pendapat kawan bicara terdapat dalam paduan fatis atuh nya. Paduan fatis yang berfungsi untuk mengukuhkan pembicaraan adalah nuhun ah, dan atuh da, sedangkan paduan yang berfungsi membentuk kalimat interogatif adalah téa lin.

Paduan fatis berfungsi untuk mematahkan pembicaraan, yakni sebanyak 1 fatis, fungsi menekankan ajakan sebanyak 4 fatis, fungsi menegaskan pembicaraan sebanyak 10 fatis, fungsi meyakinkan pembicaraan sebanyak 4 fatis, fungsi meminta persetujuan atau pendapat kawan bicara sebanyak 1 fatis, fungsi mengukuhkan pembicaraan sebanyak 4 fatis, dan fungsi membentuk kalimat interogatif sebanyak 1 fatis. Fungsi yang paling banyak adalah fungsi menegaskan pembicaraan, sedangkan fungsi mengawali dan mengakhiri pembicaraan tidak ditemukan dalam bentuk paduan fatis.Sementara berdasarkan maknanya, paduan fatis bermakna menekankan bantahan, yakni termuat dalam paduan wah $d a$, menekankan keingintahuan termuat dalam paduan tea lin, menekankan kesungguhan termuat dalam paduan mah da, héh atuh, nuhun ah, hayu ah, atuh da, hayo(h) atuh, heueuh da, dan heueuh pan. Makna menghaluskan paksaan termuat dalam paduan atuh nya, dan makna menekankan kebenaran sebuah fakta termuat dalam paduan mah pan, atuh da, dan mah ning/mah geuning. 
Paduan fatis bermakna menekankan bantahan, yakni sebanyak 1 fatis, menekankan keingintahuan sebanyak 1 fatis, menekankan kesungguhan sebanyak 12 fatis, menghaluskan paksaan sebanyak 1 fatis, dan menekankan kebenaran fakta sebanyak 6 fatis. Tidak ditemukan makna menekankan keheranan, menekankan kekesalan, menekankan kesetujuan, dan menekankan basa-basi dalam bentuk paduan fatis.Gabungan fatis ditemukan sebanyak 42 fatis (45.2\%). Gabungan fatis dapat berdistribusi dimana saja, baik di awal, tengah, maupun akhir kalimat. Gabungan fatis yang berdistribusi di awaltengah adalah nya...da..., yéh...geuning..., pan...téh..., tah...téh..., da...ning...,ah...yeuh, geuning...mah..., pan,..geuning..., téh...mah, yéh...mah..., hég...téh, geuning...téh,...nyeta...teh, dan oh...mah. Gabungan fatis yang berdistribusi di tengahtengah adalah ...mah...da..., dan ...téh...mah.... Gabungan fatis yang berdistribusi di tengahakhir adalah ...atuh...mah, ...téh...lin, ...téh...atuh, ...da...téa, ...atuh...nya, ...téh...nyah, ...mah...nyah, ...da...mah, ...mah...teh, ...atuh...teh, ...mah...geuning, ...da...nya, ...téh...tah, ...eung...mah, ...nyah...mah, ...weh...teh, ...yu...mah, dan ...nya...nya. Gabungan fatis yang berdistribusi di awal-akhir adalah halah...nya, tah...ning, tah...mah, ah...yeuh, yu...mah, dan nya...nya. Sementara itu, gabungan fatis yang berdistribusi di awal-akhir adalah teh...lin, pan...mah, da...mah, ah...teh, halah...nya, mah...teh, ah...mah, tah...ning, tah...mah, dan euh mah. Bentuk gabungan fatis yang berdistribusi di awal sebanyak 47 fatis, di tengah 64 fatis, dan di akhir 38 fatis.

Gabungan fatis yang berdistribusi di awal-tengah berfungsi untuk mematahkan, menegaskan, meyakinkan, dan mengukuhkan pembicaraan. Gabungan fatis yang berfungsi mematahkan pembicaraan adalah $a h . . . m a h . .$. dan $e u h . . . m a h . .$. , gabungan untuk menegaskan pembicaraan adalah nya...da...,yéh...geuning..., ah...mah..., pan...téh..., tah...téh..., geuning...mah..., pan...geuning..., da...téh...,yéh...mah..., hég...téh..., geuning...téh..., dan oh...mah.... Gabungan fatis yang berfungsi meyakinkan pembicaraan adalah nyéta...téh..., dan gabungan fatis yang berfungsi mengukuhkan pembicaraan adalah nya...da... dan da...ning....Gabungan fatis yang berdistribusi di tengah-tengah berfungsi untuk menegaskan dan meyakinkan pembicaraan. Gabungan fatis yang berfungsi untuk menegaskan pembicaraan adalah ...mah...da..., dan ...téh...mah....Sementara itu, gabungan fatis yang berfungsi untuk meyakinkan pembicaraan adalah ...mah...téh....

Gabungan fatis yang berdistribusi di tengah-akhir kalimat berfungsi untuk meminta persetujuan atau pendapat kawan bicara, menegaskan, meyakinkan, mengukuhkan, dan mengawali pembicaraan. Gabungan fatis yang berfungsi untuk menegaskan pembicaraan adalah ...atuh...mah, ...téh...lin, ...téh...atuh, ...atuh...nya, ...téh...nyah, ...da...téa, ...mah...nyah, ...atuh...téh, ...mah...geuning, ...da...nya, ...eung...mah, dan ...nyah...mah. Gabungan fatis yang berfungsi meyakinkan pembicaraan adalah ...téa...mah dan ...téh...tah, gabungan fatis yang berfungsi meminta pendapat atau persetujuan kawan bicara adalah ...téh...nyah dan ...mah...nyah, gabungan fatis yang berfungsi mengukuhkan pembicaraan adalah ...wéh...téh, dan gabungan yang berfungsi untuk membentuk kalimat interogatif adalah ...téh...lin dan ...téh...atuh.

Gabungan fatis yang berdistribusi di awal-akhir kalimat berfungsi untuk menegaskan pembicaraan, meyakinkan pembicaraan, meminta persetujuan atau pendapat kawan bicara, menekankan ajakan, dan mengakhiri pembicaraan. Gabungan fatis yang berfungsi menegaskan pembicaraan adalah halah...nya dan ah...yeuh, gabungan yang berfungsi meyakinkan pembicaraan adalah tah...ning dan tah...mah, fungsi untuk meminta persetujuan atau pendapat kawan bicara adalah halah...nya, gabungan untuk menekankan ajakan adalah yu...mah, sedangkan gabungan yang berfungsi mengakhiri pembicaraan adalah $y u \ldots y u$. 
Gabungan fatis yang berdistribusi di awal-tengah-akhir berfungsi untuk membentuk kalimat interogatif, menegaskan, dan meyakinkan pembicaraan. Gabungan fatis yang berfungsi membentuk kalimat interogatif adalah pan...mah dan da...mah, gabungan yang berfungsi menegaskan pembicaraan mah...teh, pan...mah dan ah...téh, sedangkan gabungan fatis yang berfungsi meyakinkan pembicaraan adalah pan...mah dan mah..teh.

Gabungan fatis berfungsi untuk mematahkan pembicaraan, yakni sebanyak 3 fatis, fungsi menekankan ajakan sebanyak 1 fatis, fungsi menegaskan pembicaraan sebanyak 46 fatis, fungsi meyakinkan pembicaraan sebanyak 23 fatis, fungsi meminta persetujuan atau pendapat kawan bicara sebanyak 4 fatis, fungsi mengukuhkan pembicaraan sebanyak 8 fatis, fungsi membentuk kalimat interogatif sebanyak 8 fatis, dan fungsi mengakhiri pembicaraan sebanyak 2 fatis. Fungsi yang kemunculannya paling banyak dalam bentuk ini adalah fungsi menegaskan pembicaraan, sedangkan fungsi mengawali pembicaraan tidak ditemukan.Gabungan fatis yang berdistribusi di awal-tengah bermakna menekankan kesetujuan, kesungguhan, kebenaran sebuah fakta, keheranan, dan kengintahuan. Gabungan fatis yang bermakna menekankan kesetujuan adalah nya...da, gabungan yang bermakna menekankan kesungguhan adalah yeh...geuning,gabungan yang menekankan keingintahuan adalah oh...mah, gabungan yang bermakna menekankan keheranan adalah geuning...teh. Gabungan fatis yang bermakna menekankan kebenaran sebuah fakta adalah nyéta..téh, pan...téh, tah...téh, da...ning, pan...geuning, da...téh, yéh...mah, dan hég...téh.

Gabungan fatis yang berdistribusi di tengah-tengah bermakna menekankan kebenaran sebuah fakta, yaitu mah...da dan téh...tah. Gabungan fatis yang berdistribusi di tengah-akhr berfungsi menekankan keingintahuan, menekankan kesungguhan, dan menekankan kebenaran sebuah fakta.Gabungan fatis yang berdstribusi di tengah-tengah dan bermakna menekankan keingntahuan adalah téh...nyah, mah...nyah, dan nyah...mah. Gabungan yang bermakna menekankan kesungguhan adalah atuh...nya, atuh...téh, mah...geuning, dan eung...mah. Gabungan yang bermakna menekankan kebenaran sebuah fakta adalah téh...lin, téh...atuh, téa...mah, da...téa, da...nya, dan téh...mah.Gabungan fatis yang berdistribusi di awal, tengah, dan akhir adalah bermakna menekankan bantahan, menekankan keingintahuan, menekankan keheranan, menekankan kesungguhan, menghaluskan paksaan, menekankan kekeslan, menekankan kesetujuan, dan menekankan kebenaran sebuah fakta. Gabungan fatis yang bermakna menekankan bantahan adalah atuh...mah dan ah...mah, gabungan yang bermakna menekankan keinginahuan adalah ah...mah dan ah...téh, gabungan yang bermakna menekankan keheranan adalah atuh...mah. Gabungan yang bermakna menekankan kesungguhan adalah ah...mah dan da...mah. Gabungan fatis yang bermakna menghaluskan paksaan adalah ah...téh dan da...mah, gabungan yang bermakna menekakna kekesalan adalah pan...mah dan atuh...mah, gabungan yang bermakna menekankan kesetujuan adalah pan...mah. gabungan yang bermakna menekankan kebenaran sebuah fakta adalah ah...mah, ah...téh, da...mah, dan pan...mah.

Gabungan fatis bermakna menekankan bantahan ditemukan sebanyak 3 fatis, menekankan keingintahuan sebanyak 10 fatis, menekankan keheranan sebanyak 5 fatis, menekankan kesungguhan sebanyak 15 fatis, menghaluskan paksaan sebanyak 4 fatis, menekankan kekesalan sebanyak 4 fatis, menekankan kesetujuan sebanyak 2 fatis, dan menyatakan kebenaran sebuah fakta sebanyak 38 fatis, sedangkan makna menekankan basa-basi tdak terdapat dalam bentuk ini.Perulangan fatis ditemukan sebanyak 2 fatis (2.1\%). Bentuk perulangan fatis hanya berdistribusi di awal kalimat, yakni sebanyak 2 fatis.Perulangan fatis euleuh-euleuh berfungsi untuk mengukuhkan pembicaraan, sedangkan perulangan fatis hеиеиh-hеиеuh berfungsi untuk menegaskan dan meyakinkan 
pembicaraan. Sementara itu, makna yang terkandung dalam perulangan fatis euleuh-euleuh adalah menekankan keheranan dan makna yang terkandung dalam perulangan heueuhheueuh adalah makna menekankan kesungguhan.Frasa fatis ditemukan sebanyak 6 fatis (6.4\%). Frasa fatis dapat berdistribusi di awal dan tengah kalimat. Frasa fatis yang berdistribusi di awal adalah assalamu'alaikum, wa'alaikumsalam, alhamdulilah, astagfirullashadzim, dan hatur nuhun, sedangkan frasa fatis insya Allah berdistribusi di awal dan tengah kalimat. Bentuk frasa fatis berdistribusi di awal sebanyak 16 fatis dan di tengah sebanyak 1 fatis. Tidak ditemukan frasa fatis yang berdistribusi di akhir kalimat.

Frasa fatis yang berdistribusi di awal berfungsi untuk menegaskan, mengukuhkan, mengawali, dan mengakhiri pembicaraan. Frasa fatis yang berfungsi menegaskan pembicaraan adalah astagfirullahal'adzim, frasa untuk mengukuhkan pembicaraan adalah alhamdulilah dan hatur nuhun, frasa untuk mengawali pembicaraan adalah assalamu'alaikum, dan frasa untuk mengakhiri pembicaraan adalah wa'alaikumsalam. Sementara itu, frasa fatis insya Allah yang berdistribusi di awal dan tengah kalimat berfungsi untuk meyakinkan pembicaraan. Frasa fatis berfungsi untuk menegaskan pembicaraan, yakni sebanyak 1 fatis, fungsi meyakinkan pembicaraan sebanyak 1 fatis, fungsi mengukuhkan pembicaraan sebanyak 2 fatis, dan fungsi mengawali serta mengakhiri pembicaraan masing-masing sebanyak 1 fatis. Tidak terdapat fungsi mematahkan pembicaraan, menekankan ajakan, meminta persetujuan atau pendapat kawan bicara, dan membentuk kalimat interogatif dalam bentuk ini.Makna frasa fatis yang berdistribusi di awal kalimat adalah menyatakan salam, membalas salam, menyatakan doa, menyatakan janji, dan menyatakan pujian atau rasa syukur. Frasa fatis yang bermakna menyatakan salam adalah frasa assalamu'alaikum, frasa yang bermakna membalas salam adalah wa'alaikumsalam, frasa yang bermakna menyatakan janji adalah insyaAllah, frasa yang bermakna menyatakan doa adalah astagfirullahal'adzim, dan frasa yang bermakna menyatakan pujan atau rasa syukur adalah alhmadulilah serta hatur nuhun. Sementara frasa fatis insyaAllah yang berdistribusi di tengah kalimat bermakna menyatakan janji.

Frasa fatis bermakna menyatakan salam, yakni ditemukan sebanyak 5 fatis, membalas salam sebanyak 5 fatis, menyatakan janji sebanyak 2 fatis, menyatakan doa sebanyak 1 fatis, dan menyatakan pujian atau rasa syukur sebanyak 4 fatis. Bentuk klausa atau kalimat fatis ditemukan sebanyak 5 fatis $(5.4 \%)$. Kalimat fatis hanya berdistribusi di awal percakapan, yakni kumaha cageur iraha balik, rék kamana, ti mana manéh, dan ngeus lila manéh di dieu. Bentuk klausa fatis yang berdistribusi di awal kalimat terdapat 6 fatis. Klausa fatis yang ditemukan seluruhnya berfungsi untuk mengawali pembicaraan atau membuka saluran komunikasi. Dalam bentuk ini tidak ditemukan fungsi mematahkan pembicaraan, menekankan ajakan, menegaskan pembicaraan, meyakinkan pembicaraan, meminta pendapat atau persetujuan kawan bicara, mengukuhkan pembicaraan, membentuk kalimat interogatif, dan mengakhiri pembicaraan.Makna yang ditemukan dalam bentuk klausa atau kalimat fatis hanya makna menekankan basa-basi. Makna menekankan bantahan, kengintahuan, keheranan, kesungguhan, menghaluskan paksaa, menekankan kekesalan, kesetujuan, dan basa-basi tidak ditemukan dalam bentuk klausa atau kalimat fatis.

\section{KESIMPULAN}

Kategori fatis selalu hadir dalam setiap percakapan (informal) bahasa Sunda Sukabumi. Bahasa Sunda Sukabumi memiliki enam bentuk kategori fatis, yakni bentuk partikel dan kata yang dapat berbentuk paduan, gabungan, maupun perulangan fatis, frasa 
fatis, serta klausa atau kalimat fatis. Berdasarkan bentuk-bentuk tersebut, bentuk yang frekuensi kemunculannya paling dominan adalah bentuk gabungan fatis. Sementara berdasarkan distribusinya, kategori fatis bahasa Sunda Sukabumi dapat berdistribusi di awal, tengah, dan akhir kalimat. Kategori fatis bahasa Sunda Sukabumi paling dominan berdistribusi di tengah kalimat.Kategori fatis bahasa Sunda Sukabumi pada umumnya berfungsi untuk mematahkan pembicaraan, menekankan ajakan, menegaskan pembicaraan, meyakninkan pembicaraan, meminta pendapat atau persetujuan kawan bicara, mengukuhkan pembicaraan, membentuk kalimat interogatif, mengawali, dan mengakhiri pembicaraan. Fungsi yang kemunculannya paling dominan adalah fungsi menegaskan pembicaraan. Makna yang termuat dalam partikel dan kata fatis (mencakup gabungan, paduan dan perulangan fatis) serta klausa atau kalimat fatis bahasa Sunda Sukabumi adalah makna menekankan bantahan, keingintahuan, keheranan, kesungguhan, menghaluskan paksaan, menekankan paksaaan, menekankan kesetujuan, menekakan kebenaran sebuah fakta, menekankan basa-basi, sedangkan makna frasa fatis adalah menyatakan salam, membalas salam, menekankan janji, menytakan doa, dan menyatakan pujian atau rasa syukur. Makna yang kemunculannya paling dominan adalah makna menekankan kebenaan sebuah fakta.

\section{DAFTAR RUJUKAN}

Achmad HP. 2012. Sintaksis Bahasa Indonesia. Tangerang: PT Pustaka Mandiri. dan Abdullah, Alek. 2008. Linguistik Umum. Jakarta: Erlangga.

Agustina. 2005. Ungkapan Fatis dalam Bahasa Minangkabau dalam Ungkapan Fatis dalam

Pelbagai Bahasa. Depok: Pusat Leksikologi dan Leksikografi Fakultas Ilmu Pengetahuan Budaya Universitas Indonesia.

Alwi, Hasan, dkk. 2003. Tata Bahasa Baku Bahasa Indonesia. Jakarta: Balai Pustaka.

Bachari, Andhika Duta. 2007. "Pemarkah Fungsi Fatis Bahasa Sunda". Masyarakat Linguistik Indonesia, Vol. 24-25, No. 2, 47-52.

Chaer, Abdul. 2007. Linguistik Umum. Jakarta: Rineka Cipta. 2008. Morfologi Bahasa Indonesia. Jakarta: Rineka Cipta.

dan Agustina, Leonie. 2010. Sosioloinguistik: Perkenalan Awal. Jakarta: Rineka Cipta.

Djatmika. 2005. Pemerolehan Ekspresi Fatis pada Anak Bilingual dalam Ungkapan Fatis dalam Pelbagai Bahasa. Depok: Pusat Leksikologi dan Leksikografi Fakultas Ilmu Pengetahuan Budaya Universitas Indonesia.

F.X. Rahyono. 2005. Intonasi dan Makna Ungkapan Fatis Sebuah Ancangan Penelitian Fonetik Eksperimental dalam Ungkapan Fatis dalam Pelbagai Bahasa. Depok: Pusat Leksikologi dan Leksikografi Fakultas Ilmu Pengetahuan Budaya Universitas Indonesia. 
Faizah, Hasnah. 2012. "Kategori Fatis dalam Bahasa Melayu Dialek Kuok". "Kategori Fatis dalam Bahasa Melayu Dialek Kuok". Laporan Penelitian.Riau: FKIP Unri.

Kartini, Tini, Saini KM, dan Mulyono, Iyo. 1985. Kedudukan dan Fungsi Bahasa Sunda di Jawa Barat. Jakarta: Pusat Pembinaan dan Pengembangan Bahasa.

Keraf, Gorys. 2007. Diksi dan Gaya Bahasa. Jakarta: PT Gramedia Pustaka Utama.

Kridalaksana, Harimurti. 2005. Dari Fungsi Fatis ke Ungkapan Fatis dalam Ungkapan Fatis dalam Pelbagai Bahasa. Depok: Pusat Leksikologi dan Leksikografi Fakultas Ilmu Pengetahuan Budaya Universitas Indonesia.

. 2007. Kelas Kata dalam Bahasa Indonesia. Jakarta: PT Gramedia Pustaka Utama.

Mahsun MS. 2007. Dialektologi. Yogyakarta: Gama Media.

Parera, Jos Daniel. 1991. Kajian Linguistik Umum Historis Komparatif dan Tipologi Struktural. Jakarta: Erlangga.

Prawiraatmaja, Dudu, dkk. 1986. Perkembangan Bahasa Sunda Sesudah Perang Dunia II. Jakarta: Pusat pembinaan dan Pengembangan Bahasa Departemen Pendidikan dan Kebudayaan.

Rachmat, Ratnawati. 2005. Ungkapan Fatis Bahasa Jawa dalam Ungkapan Fatis dalam Pelbagai Bahasa. Depok: Pusat Leksikologi dan Leksikografi Fakultas Ilmu Pengetahuan Budaya Universitas Indonesia.

Ridwan, Sakura H. dan Anwar, Miftahul Khaerah. 2011. Sintaksis.Bogor: Irham Publishing.

Robins, R.H. 1982. Sistem dan Struktur Bahasa Sunda. Jakarta: Djambatan. 1995. Sejarah Singkat Linguistik. Bandung: Penerbit ITB.

Schriffrin, Deborah. 1994. Approaches to Discourse. Cambridge: Blackwell Publisher.

Sudaryat, Yayat. 2003. Elmuning Basa. Bandung: Wahana Luang.

Tarigan, Henry Guntur. 1984. Pengajaran Sintaksis. Bandung: Angkasa.

Utorodewo, Felicia, dkk. 2011. Bahasa Indonesia: Sebuah Pengantar Penulisan Ilmiah. Jakarta: Badan Penerbit FKUI.

Waridin. 2008. "Ungkapan Fatis dalam Acara Temu Wicara Televisi”. Tesis. Tidak diterbitkan. Depok: Universitas Indonesia.

Yuwono, Untung. 2005. Pesona Bahasa. Jakarta: PT Gramedia Pustaka Utama. 
Arkhais, Vol. 06 No. 2 Juli - Desember 2015 